\title{
Urinary Neurotransmitter Testing: Considerations of Spot Baseline Norepinephrine and Epinephrine [Expression of Concern]
}

Hinz M, Stein A, Uncini T. Res Rep Urol. 2011;3:19-24.

The Editor-in-Chief and Publisher of Research and Reports in Urology (formerly Open Access Journal of Urology) wish to issue an Expression of Concern for the published article.

Concerns have been raised regarding the alleged undisclosed competing interests of some of the authors, and the level of information provided on methodology, study data and process of institutional ethical approval for the published article. Research and Reports in Urology would like to alert readers of this while our investigation is still ongoing and we will provide an update following the conclusion of our investigation.

The authors have been informed of these concerns and of our investigation.

\section{Publish your work in this journal}

Research and Reports in Urology is an international, peer-reviewed, open access journal publishing original research, reports, editorials, reviews and commentaries on all aspects of adult and pediatric urology in the clinic and laboratory including the following topics: Pathology, pathophysiology of urological disease; Investigation and treatment of urological disease; Pharmacology of drugs used for the treatment of urological disease. The manuscript management system is completely online and includes a very quick and fair peer-review system, which is all easy to use. Visit http://www.dovepress.com/ testimonials.php to read real quotes from published authors. 